\title{
Filosofia na formação profissional: por que ter valores políticos, éticos e estéticos na formação profissional é importante?, de Antônio
} Joaquim Severino. São Paulo: Cartago Editorial, 2017.

\author{
Mércia Aparecida Monteiro Desenzi \\ Tradutora e Mestre em Educação pela Universidade Nove de Julho - Uninove, São Paulo - \\ SP, Brasil. \\ merciadesenzi@gmail.com
}

Em vista dos avanços tecnológicos, a eficácia técnica passou a ter um papel fundamental na sociedade contemporânea em detrimento da formação filosófica e humana. Isto afetou o ensino superior, conduzido ao pragmatismo e à capacitação técnica do universitário focada no mercado de trabalho. As Diretrizes Curriculares dos cursos superiores comprovam este direcionamento e, tanto os Institutos de Educação Superior públicos, quanto os confessionais, estão sendo sublimados pelo novo modelo mercantilizado de ensino superior, que prepara o aluno para funções técnico-operacionais, para o mundo da produção e não o induz às análises e reflexões sobre o sentido de sua formação.

Com licenciatura e mestrado em Filosofia pela Universidade Católica de Louvain na Bélgica (1962 e 1964), doutorado em Filosofia pela PUC-São Paulo (1972) e livre-docência em Filosofia da Educação pela USP (2000), Antônio Joaquim Severino atuou como professor de Filosofia da Educação na FEUSP e atua no Programa de pós-graduação em Educação na Uninove.

Dentre suas diversas publicações, cada um dos seis capítulos desta obra em particular dedica-se a propor uma reflexão do graduando sobre o sentido de sua formação e a razão de estar na universidade. 
No primeiro, intitulado "A universidade brasileira e sua destinação", Severino aponta os obstáculos que a instituição enfrenta para garantir sua contribuição para o desenvolvimento social de todas as camadas da sociedade, os equívocos na concepção e sua condução egoística, sua falta de identidade, contradições internas e riscos externos, como a falta de políticas governamentais em prol do interesse público, de planejamento e de recursos humanos, técnicos e financeiros. Hoje, desvalorizadas principalmente pela perda de prestígio das carreiras profissionais e oportunidades restritas no mercado de trabalho, as universidades sofrem corrosões internas: as públicas, fechando-se às inovações em razão das burocracias, e as privadas, interessadas em atender as demandas, sem priorizar a qualidade na formação desses jovens. $\mathrm{O}$ autor divide a formação universitária em três esferas necessárias: apropriação do conhecimento científico, o domínio das habilidades técnicas e o desenvolvimento da sensibilidade política, ética e estética junto à percepção da condição humana e do existir em uma sociedade histórica.

No segundo capítulo, "As profissões como cuidado com a existência humana", trata da necessidade de equilibrio e harmonia nos relacionamentos entre indivíduos, com a natureza e com os bens culturais, já que a vida humana se desdobra em um processo de convivência, sobrevivência e consciência. O que não é uma tarefa fácil, visto que as mesmas forças que humanizam, podem também desumanizar, que o conhecimento pode ou não ajudar na superação das fragilidades da espécie e contradições. Afirma que os aspectos fundamentais na formação de qualquer profissional são: o cuidado com a vida humana, o respeito aos valores e os processos de aquisição de conhecimento, ou seja, antropológicos, axiológicos e epistemológicos.

"A contribuição pedagógica da filosofia na formação universitária" no terceiro capítulo, descreve como é importante que as universidades, além da habilitação técnico-profissional, invistam também na formação filosófica dos estudantes, na formação integral que esclareça o sentido de sua existência e abram seus olhos diante de falsas ideologias. Já que filosofar é um ato de reflexão, é pensar na realidade, no significado do existir humano na história, o objetivo deve ser de tornar o aluno um pensador capaz de "inserir o micro-sentido de seu existir pessoal no macro-sentido de seu existir social".

Em "A condição humana: imanência e transcendência” no quarto capítulo, Severino constata a prioridade da sobrevivência e a relação do homem com a natureza, sua intervenção sobre ela para a 


\section{DESENZI, Mercia Aparecida Monteiro}

e-ISSN: 2525-3514

manutenção da vida sob a forma de trabalho coletivo. Diferentemente dos animais que se adaptam à natureza instintivamente, os homens a modificam intencionalmente para que ela se adapte a ele. Alerta que a existência do homem se dá na tríplice esfera do trabalho, da sociabilidade e da cultura, itens sem os quais nos desumanizamos.

No quinto capítulo "Ética e política na prática profissional”, considera que todos os homens possuem uma sensibilidade moral e avaliam suas ações e as dos outros, julgam e impõem atitudes e comportamentos aceitos em sua sociedade, apesar do livre arbítrio em seguir ou não. As ações moralmente boas são universais, já os valores pessoais são individuais e sociais ao mesmo tempo, portanto a avaliação ética de uma ação refere-se a uma valoração coletiva.

Cita que o compromisso da aplicação do conhecimento na construção da cidadania está atrelado à ética e cabe ao ensino superior auxiliar na construção da cidadania do "sujeito pessoal" e da democracia para o “sujeito social”. Complementa que todas as sensações subjetivas e derivadas dos sentidos são estéticas e toda experiência estética envolve uma avaliação ética e epistêmica. Como esses campos encontram-se no território da subjetividade, estão sujeitos à alienação e à manipulação ideológica.

Em "Conhecimento, ciência e tecnologia" no sexto capítulo, afirma que a meta da formação universitária é de "assegurar um saber competente para um fazer eficiente", é profissionalizante, sem se restringir à formação técnica especializada, já que a prática humana não é robotizada, mas intencionada. $\mathrm{O}$ homem precisa sobreviver e estabelecer relações significativas entre os fatos e sua existência, entre o que é objetivo e subjetivo e desenvolver seu conhecimento científico, estético-valorativo e filosófico para a atribuição de um sentido a sua existência na história e clareamento das falsas ideologias que levam à alienação.

Severino conclui que o propósito do “ensaio" foi argumentar quanto à importância da filosofia nos currículos dos cursos universitários, das responsabilidades da universidade que vão além da instrução técnica, mas da formação integral dos aprendizes nos campos pessoal, cultural, ético-político e domínio do processo de construção de seu próprio conhecimento, da condução de uma existência humanizada e da superação das limitações em um país tão carente.

Cadernos de Pós-graduação, São Paulo, v. 18, n. 2, p. 11-14, jul/dez. 2019 
Esta obra propõe aos universitários raciocinar e ponderar sobre o propósito de sua formação. Importante para os estudantes, professores, coordenadores, gestores e todos os envolvidos com a educação, pois mostra que só a formação técnica, desprovida de uma reflexão sobre o sentido da formação, desumaniza e que o aluno precisa atingir sua autonomia e construir seu próprio conhecimento. Visto que o objetivo da educação é promover a compreensão de que somos seres sociais, históricos e providos de subjetividade, cabe à educação superior, além da formação técnico-profissional e o preparo para o mercado de trabalho, proporcionar sua formação integral como ser humano autônomo, o desenvolvimento de um "ser original" a um "vir a ser cultural". 